\title{
Multiple functions and essential roles of nuclear receptor coactivators of bHLH-PAS family
}

\author{
Pecenova L, FARKas R \\ Laboratory of Developmental Genetics, Institute of Experimental Endocrinology, Biomedical Research Center, \\ Slovak Academy of Sciences, Bratislava, Slovakia \\ E-mail: ueenfark@savba.sk
}

\begin{abstract}
Classical non-peptide hormones, such as steroids, retinoids, thyroid hormones, vitamin $\mathrm{D}_{3}$ and their derivatives including prostaglandins, benzoates, oxysterols, and bile acids, are collectively designated as small lipophilic ligands, acting via binding to the nuclear receptors (NRs). The NRs form a large superfamily of transcription factors that participate virtually in every key biological process. They control various aspects of animal development, fertility, gametogenesis, and numerous metabolic pathways, and can be misregulated in many types of cancers. Their enormous functional plasticity, as transcription factors, relates in part to NR-mediated interactions with plethora of coregulatory proteins upon ligand binding to their ligand binding domains (LBD), or following covalent modification. Here, we review some general views of a specific group of NR coregulators, so-called nuclear receptor coactivators (NRCs) or steroid receptor coactivators (SRCs) and highlight some of their unique functions/roles, which are less extensively mentioned and discussed in other reviews. We also try to pinpoint few neglected moments in the cooperative action of SRCs, which may also indicate their variable roles in the hormone-independent signaling pathways.
\end{abstract}

Key words: nuclear receptors, coactivators, bHLH-PAS family

Nuclear receptor coactivators (NRCs) or steroid receptor coactivators (SRCs) are broad/wide (specific) group of transcription-regulating nuclear proteins, first discovered as auxiliary factors, recruited by members of the nuclear receptor (NR) superfamily. The three basic family members, SRC-1 (NCoA1), SRC-2 (NCoA2/Grip1/Tif2), and SRC-3 (NCoA3/ CIP/AIB1/ACTR/RAC3/TRAM-1), belong to the structurally homologous p160 family of coactivators. The common feature of this family is the presence of basic-helix-loop-helix (bHLH) and period-aryl hydrocarbon receptor nuclear translocator protein (Arnt)-Single-minded protein (PAS) domains in their N-terminal region (Figure 1). The bHLH-PAS region facilitates DNA binding, protein-protein interactions with other coregulators and transcrip- tion factors (TFs) and contains a canonical nuclear localization signal (Awais et al. 2007; Chang and Wu 2012; Zelenko et al. 2012; Endler et al. 2014). More centrally located is a serine/threonine-rich domain, the phosphorylation status, which influences the SRC activity. Following is a receptor and TF interaction domain, containing two or three LXXLL motifs (socalled NR-boxes) that facilitate NR binding. Near the C-terminus, there are two activation domains (AD1 and $\mathrm{AD} 2$ ) that interface with other coregulators, such as CBP, p300, CARM1, and PRMT1. Although the activities of CBP and p300 are consistent with the accepted functions of a coactivator, these proteins are now considered to be ubiquitous integrative components of virtually every eukaryotic transcription complex (Black et al. 2006; Pugh 2006; Tyteca et al.

Corresponding author: Robert Farkas, PhD., Laboratory of Developmental Genetics, Institute of Experimental Endocrinology, Biomedical Research Center, Slovak Academy of Sciences, Dubravska cesta 9, 84505 Bratislava, Slovakia; phone: (+421 2) 3229-5235; fax: (+421 2) 5477-4284; e-mail: ueenfark@savba.sk 
Figure 1. Schematic presentation of various bHLH-PAS proteins demonstrated in eukaryotic metazoans, including ARNT, Tango, AhR, AhRR, HIF-1, Sima, Trachealess, Single-minded, BMAL, and all three SRCs. Note substantial size differences between the superfamily members, whereas all they share N-terminally located bHLH and PAS domains; majority has twin-PAS consisting PAS-A and PAS-B domains. Several members display Glnand Ser-rich motifs in their Cterminally positioned regions.

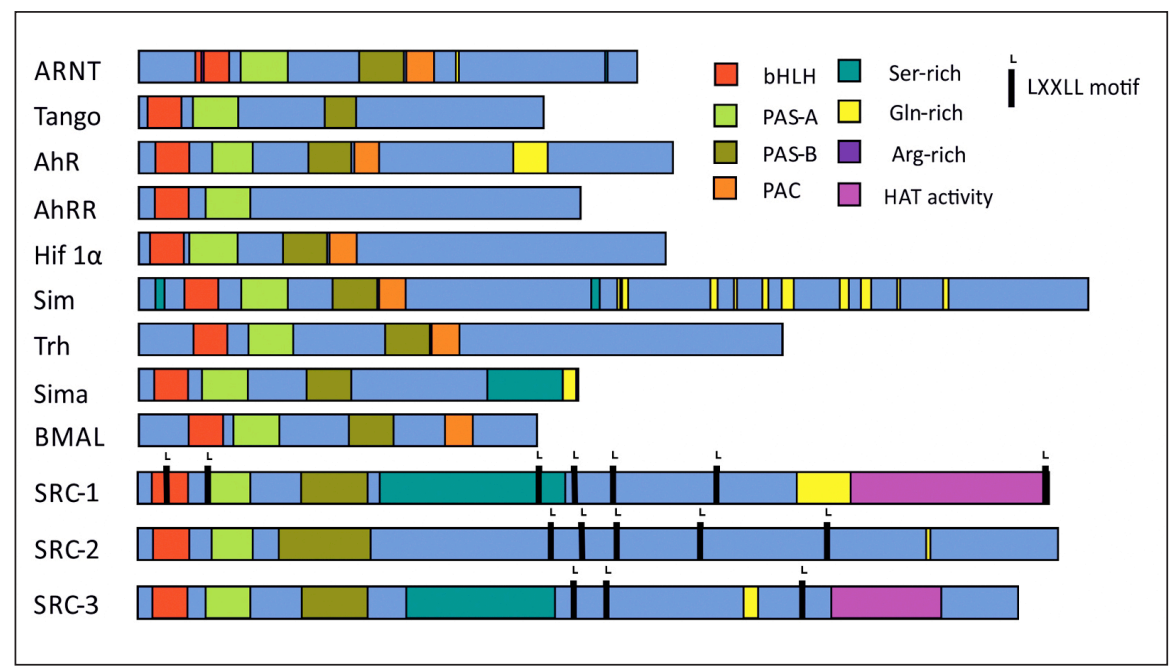

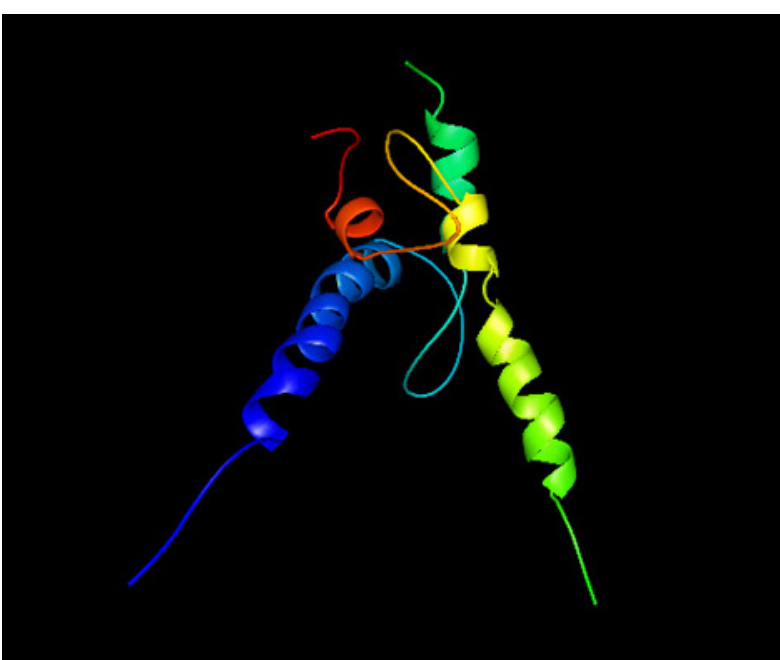

Figure 2. Crystallographic 3D structure of bHLH domain of human Upstream Stimulatory Factor protein (1AN4. pdb) composed of several $\alpha$-helices X-ray diffracted at $2.9 \AA$ resolution.

2006). The SRCs are involved in the regulation of almost all the aspects of the gene expression, including transcriptional initiation, cofactor recruitment, elongation, RNA splicing, post-translational modification (PTM) of NRs/coregulators, and chromatin components (Dasgupta et al. 2014).

In fact, both bHLH and PAS proteins are classes of their own. The bHLH is a protein structural motif (Figure 2) that identifies a family of metazoan transcription factors (Murphy et al. 2007; Weber et al. 2014; Stashi et al. 2014), characterized by two a-helices connected by a loop. Transcription factors

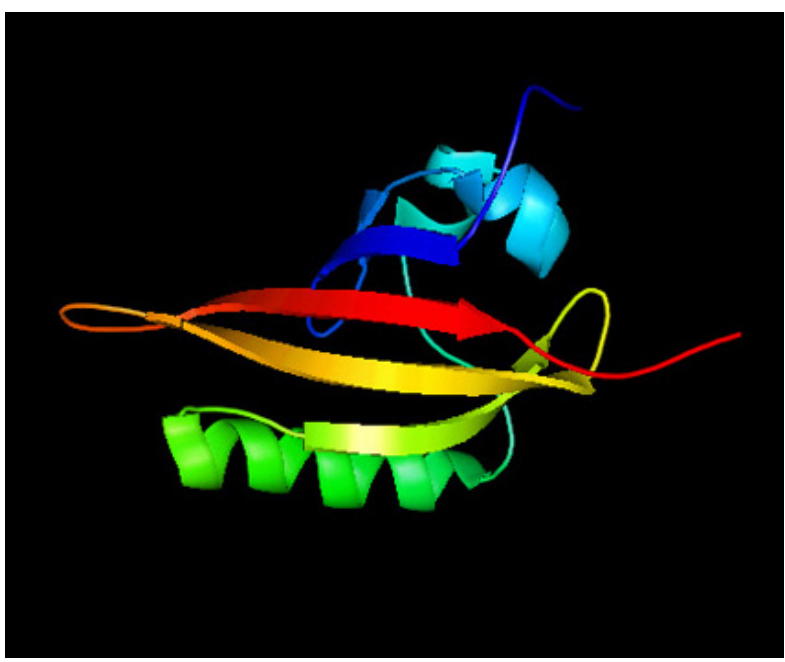

Figure 3. The 3D structure of PAS domain of human ARNT (HIF1 $\beta$ ) protein (1X0O.pdb) obtained by NMR. Note the sandwich made four antiparallel $\beta$-sheets (blue, red, yellow, light green) and a single longer $\alpha$-helix (green) at the bottom.

bearing this domain are dimeric, each with one helix containing basic amino acid residues that facilitate DNA binding. One helix is usually smaller and due to the flexibility of the loop allows dimerization by folding and packing against another helix. The larger helix typically contains the DNA-binding regions. The bHLH proteins usually bind to a consensus sequence called an E-box, CANNTG (Chaudhary and Skinner 1999). The canonical E-box is CACGTG (palindromic), however, some of the bHLH transcription factors, notably those of the bHLH-PAS family, bind to the related non-palindromic sequences, which are simi- 
lar to the E-box. Transcription factors that belong to the bHLH family play fundamental role in numerous developmental programs, including neurogenesis, myogenesis, hematopoiesis, sex determination, etc. (Littlewood and Evan 1994; Farah et al. 2000; Hjalt 2004; Jones 2004; Stashi et al. 2014; D'Rozario et al. 2016). On the other hand, the PAS domain (Figure 3) is present in many signaling proteins, found in a large number of organisms from bacteria to humans, where it functioning as a signal sensor composed of several antiparallel $\beta$-sheets forming a bunch or sandwich (Ponting and Aravind 1997; Hefti et al. 2004; Stashi et al. 2014). Many PAS-domain proteins, which are involved in variety of activities, including neural development, circadian rhythms or dioxin and other toxins binding, often detect their signal by a way of an associated cofactor. The mammalian bHLH-PAS proteins, notably of SRC/NRC family, have regularly two PAS domains of approximately 50 to 70 amino-acid residues (known as PAS A and PAS B), separated by about 80 to 150 residues that are poorly conserved. The existence of cofactors, termed co-activators or adapters, was first suggested by a transcriptional squelching between the progesterone and estrogen receptors (Hong et al. 1997; Shibata et al. 1997; Li and Chen 1998; Leo and Chen 2000). Corepressors have also been postulated to contribute to the silencing function of an unliganded thyroid hormone receptor (TR). Onate et al. (1995) have cloned the first functional coactivator, termed steroid receptor coactivator 1 (SRC-1) that appears to be a general coactivator for several steroid receptors tested, which enhances transactivation of steroid hormone-dependent target genes. Subsequently, more co-activators have been reported, including the SRC-1 related proteins, TIF2 and GRIP1, and other putative and unrelated co-activators, such as ARA70, Trip1, RIP140, and TIF1 (Nagy et al. 1999; Hsu et al. 2003; van de Wijngaart et al. 2006, 2012; Dasgupta et al. 2014; Stashi et al. 2014). In addition, another co-activator CREB-binding protein (CBP) has been shown to enhance the steroid receptor-dependent target gene transcription. CBP and SRC-1 interact and synergistically enhance the transcriptional activation by the ER and PR. Therefore, a ternary complex (consisting of liganded steroid receptor dimer, SRC-1, and CBP) must be form to achieve an increase in the rate of hormoneresponsive gene transcription.

\section{How hormonal signaling works}

NRs are unique transcription factors composed of three modulatory domains: N-terminal transactivation domain (NTD), highly conserved and ordered
DNA binding domain (DBD), and C-terminally positioned also highly ordered ligand binding domain (LBD). NRs can be categorized not only based on the nature of their DNA binding sites, but also the fact whether they form homodimers, such as the androgen receptor (AR), glucocorticoid receptor (GR), mineralocorticoid receptor (MR), estrogen receptor (ER), and progesterone receptor (PR) or heterodimers, such as the retinoic acid receptor (RAR), thyroid hormone receptor (TR), ecdysteroid receptor (EcR), farnesoid X receptor (FXR), liver X receptor (LXR), peroxisome proliferator-activated receptors (PPARs), and vitamin $\mathrm{D}_{3}$ receptor (VDR). Heterodimerizing group of receptors requires one of the three isoforms of the universal and promiscuous dimerization partner, retinoid $\mathrm{X}$ receptor (RXR), a natural ligand, which is the 9-cis retinoic acid (Norman 1992; Kastner et al. 1995; Mouchon et al. 1999; Laffitte et al. 2000; Wolf 2000; Pogenberg et al. 2005). Generally, after transportation through the cell membrane, ligand is taken up into the pocket of NR LBD (LBP). Ligand binding by NR is considered as an initial step in the hormone action (Yamamoto 1985; Evans 1988; Chen and Evans 1995; Mangelsdorf et al. 1995; Nagy et al. 1999; King-Jones and Thummel 2005; O’Malley 2007; Heldin et al. 2016). It is an allosteric mechanism, which allows conformational change and dimer formation, then leading, among others, also to accessibility of coactivators and release of corepressor proteins if previously complexed with NR. The ligand bound receptor can not only dimerize, but it also binds to its cognate DNA, so called hormoneresponse element (HRE) from where it regulates the gene transcription (Hong et al. 1997; Mouchon et al. 1999; Klinge et al. 2004; Heldin et al. 2016).

The LBD domain of NRs forms a defined globular structure, in which eight to twelve $a$-helices, as well as 1 to $4 \beta$-sheets are arranged together in an antiparallel three-layered sandwich (Figure 4). All so far obtained crystal structures of NR LBDs indicate that the ligands are completely engulfed inside LBP in the interior of the protein. As documented by numerous $\mathrm{X}$-ray crystallographic studies, the ligand binding is accompanied by a transition from the unbound to bound states what means that the C-terminal helix 12 (H12) moves from an open to a closed conformation in a manner termed as "mousetrap" model (Parker and White 1996; Wurtz et al. 1996). This conformational change results in a completion of the AF-2 pocket (contributed by helices $\mathrm{H} 3, \mathrm{H} 4 / 5$, and $\mathrm{H} 12$ ) that forms a conserved surface exposing hydrophobic groove (Darimont 2003). Coactivators interact with this AF-2 groove of NRs through a highly con- 


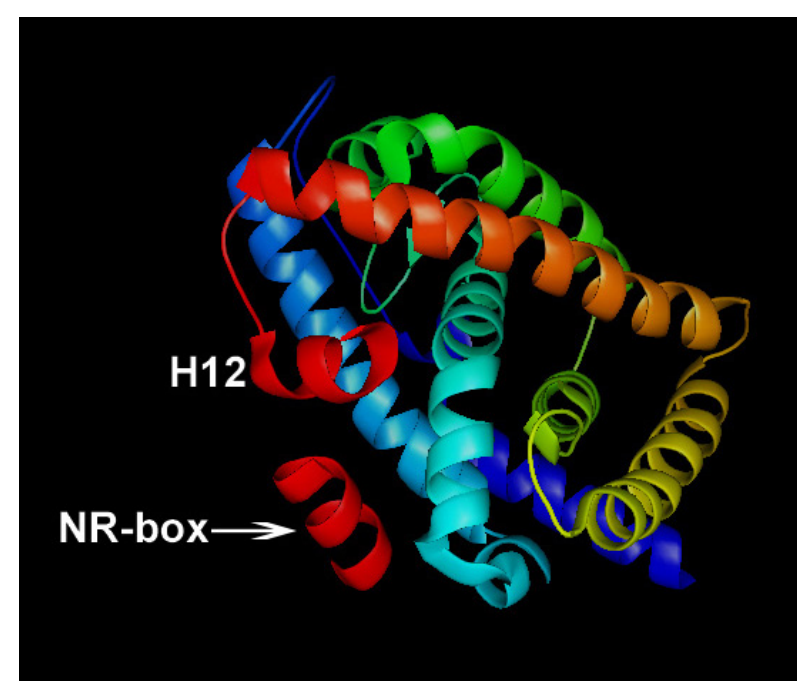

Figure 4. Rendered image of the X-ray crystallographic 3D structure of a single LBD of RAR (3KMR.pdb) diffracted at $1.8 \AA$ resolution. Note the indicated position of helix H12 and LXXLL peptide (NR-box) co-crystallized in the vicinity with a charge clamp of RAR (both red).

served LXXLL consensus sequence (where L stands for leucine and $\mathrm{X}$ is any amino acid) also called NRbox, which bind as amphipathic $a$-helices with the hydrophobic $\mathrm{L}$ residues, arranging themselves into three hydrophobic subpockets found in the AF-2. In the absence of a bound ligand, $\mathrm{H} 12$ is positioned such that the moieties, forming the AF-2, are distorted and exposed as a corepressor-binding interface or simply not binding any coregulator (Shibata et al. 1997; Leo and Chen 2000; Dutertre and Smith 2003; Mita et al. 2010; Demizu et al. 2013). By other words, ligand binding results in a repositioning of $\mathrm{H} 12$ in the LBD thus enabling the recruitment of SRC coactivators. SRCs interacting with NRs via NR-boxes facilitate the transcription via histone acetylase (HAT) activity intrinsic to SRC (Spencer et al. 1997; Torchia et al. 1997; Utley et al. 1998; Sterner and Berger 2000; Sachs and Shi 2000; Sachs et al. 2001; Black et al. 2006; Pugh 2006; Tyteca et al. 2006). In addition, the activation domain 1 (AD1) of SRCs binds to the C-terminal SRC interaction domain (SID) of p300 as well as its homolog, the cAMP response element-binding (CREB) protein (CBP) (Li and Chen 1998; Sheppard et al. 2001; Dutertre and Smith 2003; Ding et al. 2015). The p300/CBP complex plays an important role in the transcription process through connecting other transcriptional activators, basal transcription factors, chromatin remodeling proteins, and HATs to the transcriptional machinery (Zhou et al. 1998;
Vo and Goodman 2001; van de Wijngaart et al. 2012; Zelenko et al. 2012; Wang et al. 2014).

Numerous structural and in silico studies on NRs have documented the importance of the SRCs-NRs interaction for hormonal signaling. For example, comparison of farnesoid X receptor (FXR) LBD simulations with and without ligand-LBD interaction has revealed that the H11-H12 loop is fundamental in stabilizing $\mathrm{H} 12$ to be able to bind NR box of SRC (Costantino et al. 2005; Mackinnon et al. 2014). In the $\mathrm{AR}$, a conserved proline at position 892, located at the H12, has been shown to be critical for the proper function as mutation of this residue, rendered the receptor inactive due to a distorted, unstructured, and misplaced H12 thus blocking interaction with SRC's NR box (Elhaji et al. 2006). Furthermore, mutation of residue 887 in $\mathrm{H} 11$ of $\mathrm{AR}$ results in $\mathrm{H} 12$ being locked in the active conformation leads to antagonist resistance (Bisson et al. 2007). The role of H3 in the allosteric movement of $\mathrm{H} 12$ has been demonstrated via mutations of residue 280, a residue that does not directly interact with the ligand but modulates the coactivator binding. In the TR, mutations of residue 280 significantly reduce the overall ligand binding affinity from $29 \%$ (I280M) to $100 \%$ (I280R and I280K) (Souza et al. 2011). Molecular dynamic (MD) simulations suggest that the mutations indirectly block either the coactivator or corepressor activity or both. Indeed, both the I280R and I280K mutations were found to form salt bridges between the E457 in H12 and LBP, stabilizing $\mathrm{H} 12$ in a conformation that may prevent either coactivator or corepressor binding. On the other hand, the I280M mutation blocked the corepressor binding and it appears that enhances the coactivator affinity, suggesting stabilization of $\mathrm{H} 12$ in agonist conformation." Moreover, mutation of residue 774 in $\mathrm{H} 5$ of the AR has been shown to sufficiently reduce AR ligand binding activity to cause complete androgen insensitivity syndrome (CAIS) (Wu et al. 2003; Mackinnon et al. 2014). Temperature-dependent MDs data have demonstrated that this thermolabile mutant prompted significant structural distortion above $20^{\circ} \mathrm{C}$ that induces $\mathrm{H} 1-\mathrm{H} 2$ loop rearrangement followed by an H4-H5 loop distortion and a subsequent H5 rearrangement, indicating that a temperature-dependent mechanism is involved in the development of CAIS.

This type of studies was able to provide deeper insights into the understanding of the dynamics of allosteric consequences (population of NR conformational ensembles) of ligand binding to NRs. MD simulations of a GR-antagonist complex have shown that while the antagonist can be sterically compatible with an H12 agonist position the ligand serves 
to induce rapid $\mathrm{H} 12$ conformational rearrangements (Presman et al. 2010). These observations have suggested that the ligand does not induce one particular receptor conformation but instead changes the dynamic equilibrium of $\mathrm{H} 12$ that results in several conformational states. Similar behavior has also been reported for PPAR $\gamma$ bound to either of the agonist MRL20 or MRL24. Using a combination of nuclear magnetic resonance (NMR), hydrogen-deuterium exchange (HDX) and molecular docking Hughes et al. (2012) have found that ligands sample multiple binding modes, in which the most populated binding mode occurs between 62\% (MRL24) and 91\% (MRL20) of the time. In an alternative approach, using ancestral steroid NR reconstruction nanosecond MD simulations has been shown that the proteinligand complex's ability of sampling a huge number of conformational microstates could be impeded by the introduction of an excess of interaction partners (Harms et al. 2013). Interestingly, subtle changes in the structure of the NR, via the introduction of two mutations, resulted in transitions among frustrated ensembles of suboptimal states that resulted in a 70000-fold reduction in specificity (Mackinnon et al. 2014).

\section{Originally simple scheme becoming more complicated}

The above described scheme of ligand and NR actions was recognized and supportingly constructed over two decades. In the recent years, it is facing to several new challenges, which on the one side complicate the original simple view, but on the other side it provides more comprehensive characteristics of the entire system helping to explain several previously not understood observations. In fact, since the beginning to make this notion simpler, it should be said that previous static view nowadays start to preoccupy more dynamic contours. As indicated above, upon binding of the ligand to the LBP, the spatially distinct AF-2 coactivator binding site, is formed via a reorganization of the surface-exposed hydrophobic cleft that involves $\mathrm{H} 3, \mathrm{H} 4-5$, and $\mathrm{H} 12$ ( $\mathrm{He}$ et al. 2000; Darimont 2003; Osguthorpe and Hagler 2011; Osguthorpe et al. 2012; van de Wijngaart et al. 2012). However, employment of several modern techniques, including fluorescence spectrometry, absorption and emission spectroscopy, and calorimetry that collectively can be named as molecular dynamics (MD), have revealed that ligand binding to AR led to a biphasic receptor rearrangement that involves population of a molten globule-like intermediate state, caus- ing a substantial rearrangement of the AF-2 binding surface (Jasuja et al. 2009; Zakharov et al. 2011). Further analysis of the communication between the AR with ligands and coactivators by dynamic crosscorrelation maps from MD simulations and thermodynamic data has revealed a bidirectional effect on binding at the AR ligand and AF-2 sites (Xu et al. 2011; Buzon et al. 2012; Mackinnon et al. 2014; Gallastegui et al. 2015). Binding of the dihydrotestosterone to the AR LBD resulted in the opening of the LBD. What become curious, however, is that the recruitment of the SRC coactivator to AR has to be found to also enable the opening of the LBD pocket. In addition, nanosecond time-scale MD simulations have revealed that a second coactivator peptide was able to bind along $\mathrm{H} 3$ of the FXR and the peptide position was modified by the binding of the ligand and the first coactivator (Costantino et al. 2005). Fidelak et al. (2010) have used normal mode of PPAR $\gamma$ analysis to show the existence of a network of conformations derived from low-frequency collective motions that couples different physiologically important interfaces of the LBD. In these simulations, they have observed that mutation of the $\mathrm{H} 12$ Y473 residue was sufficient to disrupt full agonist binding by uncoupling H12 from $\mathrm{H} 3, \mathrm{H} 4 / 5$ and $\mathrm{H} 10 / 11$ and thus indicated hydrophobic cleft misformation (Fidelak et al. 2010). On the case of ERs, we can document an example of a synergism between transactivation function 1 (AF-1) and AF- 2 of ERa mediated by steroid receptor coactivator protein-1, which requires AF-1 $\alpha$-helical core for a direct interaction between the $\mathrm{N}$ - and C-terminal domains. This is functionally achieved by bridging coactivators, such as CEBP binding protein/p300 and members of the p160 subfamily, such as SRC-1. Glutathione-S-transferase pulldown assays have demonstrated that the AF-1 core is able and sufficient for the ER $\alpha \mathrm{N}$-terminal region to interact with SRC-1. In the presence of the ERa ligand-binding domain an enhancement of this recruitment has been observed, being dependent on the direct interaction between the N-terminal B domain and the ligand-binding domain (Metivier et al. 2001).

In order to identify the underlying mechanism of coactivator binding, Carlsson et al. (2005) have used a series of $10 \mathrm{~ns} \mathrm{MD}$ simulations of the wild type (wt) GR as well as its A571M, A573Q and A571M/A573Q mutations. They have found that the mutations conferred an important shift in both the structural and dynamic properties of the GR LBD. When the biological activity increase was induced via mutation, the distance between the $\mathrm{H} 12$ and the N-terminal-facing aspect of $\mathrm{H} 3$ decreased and this trend was also found 
between $\mathrm{H} 3$ and the C-terminal-facing part of H11. Moreover, $\mathrm{H} 4$ was seen to move closer to $\mathrm{H} 12$, whereas $\mathrm{H} 5$ increased its distance from H12. Combination of these structural shifts has resulted in a modified binding cleft for the coactivator peptide. Using correlation analyses for each residue, they detected an overall reduction of $10-25 \%$ in backbone fluctuation associated with increased biological activity (from wt to the double mutant). This effect has been found to be most pronounced in the loops preceding the $\mathrm{H} 3$ and $\mathrm{H} 12$ helices, where a $40-70 \%$ reduction was observed. Together, they concluded that the mutationinduced rearrangement of the AF-2 helices facilitates coactivator binding by lowering energetic costs for receptor coactivator complex formation, and the reduced fluctuations that improved steric interaction may improve binding affinity through lowered entropic costs for binding. Yet, despite the evidence in favor of cofactor pocket remodeling, they point out that the low nano-second timescale they employed does not permit the incorporation of slow protein events such as folding or interdomain movements. Perhaps, the most interesting observation they have found is that "in all simulations of wt and mutant models, the H12 remains in the canonical agonist position and displays low $\mathrm{Ca}$ fluctuations in both the apo- and holo-structure model". They have concluded that the fluctuation of $\mathrm{H} 12$ residues is virtually uncorrelated to biological activity in the four complexes investigated. They attribute the difference in their simulation with other results that correlate differences in $\mathrm{H} 12$ position and dynamics with roles in activity due to the presence of the $\mathrm{C}$-terminal coil that proceeds the GR H12 (a feature that has been absent in other NRs such as AR), which they speculate immobilizes H12.

\section{Where the SRCs act}

Originally, each individual SRC has been identified as coactivator of a particular NR. More specifically, SRC-1 has been shown to interact with ER and PR to regulate uterine function, with loss of SRC-1 decreasing uterine growth during the development (Walsh et al. 2012). Moreover, SRC-1 is an important regulator in the progression of endometriosis (Han et al. 2012). In the breast cancer, SRC-1 plays a role of potential oncogene associated with poor outcome prognosis, with roles in cell migration and metastasis (Qin et al. 2009). In the case of SRC-2, its loss in mice (Ncoa2-/Ncoa2-) affects the whole-body physiology with growth retardation and reduced adiposity. Defects in the spermatogenesis and testicular degeneration have been observed in adult male $\mathrm{Ncoa2}^{-} /$
Ncoa2- mice (Gehin et al. 2002). SRC-2 also plays a role in the cancer development. It is amplified in the prostate cancer. Translocations of SRC-2 with monocytic leukemia, zinc-finger protein (MOZ) have been found in cases of acute myeloid leukemia (Shiota et al. 2009; Taylor et al. 2010). Similarly, SRC-3 ablation in mice $\left(\mathrm{Ncoa}^{-} / \mathrm{Ncoa}^{-}\right)$results in a decreased growth, development, and reduction of circulating estrogen that delays the puberty onset (Xu et al. 2000). As an oncogene, SRC-3 has been extensively studied in various cancers, but mostly, as an amplified gene, in breast cancer with defined molecular roles in cell growth, epithelial-mesenchymal transition (EMT), and Her2 signaling (Osborne et al. 2003; $\mathrm{Xu}$ et al. 2009). Similarly to SRC-1, SRC-2 functions as either a coactivator or a corepressor for GR (Gupte et al. 2013). When SRC-2 is recruited directly to the p65 subunit of nuclear factor $\mathrm{kB}(\mathrm{NF}-\mathrm{kB})$ and activator protein 1 (AP-1), it acts as a corepressor for GR and decreases gene expression in the inflammatory response (Gupte et al. 2013). The interplay of SRC-2 with both coactivator and corepressor for GR mediates inflammatory and metabolic signaling (Uhlenhaut et al. 2013). SRC-3 coactivates the progesterone receptor (PR) in the pituitary cells. This interaction is increased by gonadotropin releasing hormone (GNRH) or progesterone treatment (An et al. 2006). Loss of SRC-3 in females increases the anxiety responses, suggesting a dynamic interplay between the SRCs and the regulation of stress responses (Stashi et al. 2013). SRC-3 expression in the brain changes by the age, being higher in young (i.e. 25 week old) and lower in old male mice (i.e. 70 week old). Likewise SRC-3, in which expression also decreases in pluripotent cells after differentiation (Paramanik and Thakur 2011; Percharde et al. 2012). Each of the SRCs plays a prominent role in the hypothalamicpituitary-adrenal-axis (HPA axis), with SRC-1 regulating $\mathrm{CRH}$ production and feeding behaviors in the hypothalamus. SRC-3 is being a PR coactivator for the gonadotropin $\alpha$-subunit promoter. Within the adrenal glands, SRC-2 is a major regulator of the corticosterone synthesis. SRC-1 and SRC-2 also play an important regulatory role in the cholesterolmediated signaling via the liver $\mathrm{X}$ receptor (LXR)/ retinoid X receptor (RXR) heterodimer, which is important not only in lipid and xenobiotic metabolism, but also in the cholesterol regulation (Son and Lee 2010; Percharde et al. 2012). SRC-2 coactivation of LXR/RXR is crucial for the cholesterol biosynthesis in Sertoli cells of the testis and loss of SRC-2 leads to an accumulation of cholesteryl esters, which may explain the hypofertility in aging males (Mascrez et 
al. 2004). Inflammation and metabolism are inherently linked as NRs regulate gene programs that control both of these processes. SRC-1, together with other coactivators and NRs, contributes to cytokineinduced hepatic metabolic changes during the acute phase response (APR) (Wang and Burke 2008). SRC1 expression decreases during the APR (Kim et al. 2007). Inflammation-induced APR alters metabolism with interleukin 1 (IL-1) or tumor necrosis factor (TNF) treatment decreasing LXR, RXR, PGC1- $\alpha$, and SRC-2 expression, resulting in a blunted LXRmediated APR (Wang 2005). Additionally, several cholesterol intermediates affect SRC-1 and SRC-2 binding to NRs. Both SRC-1 and SRC-2 show preferential recruitment to LRH-1 upon medium-chain phospholipid binding, but are inhibited by longchain phospholipids (Musille et al. 2012). In steroid biosynthesis, protein inhibitor of activated STAT- $\gamma$ (PIAS $\gamma$ ) can inhibit SRC-1 binding to LRH-1 on the Cyp1lal promoter through competitive binding, thereby decreasing steroid production (Hsieh et al. 2009). Similarly, binding of 24 S-hydroxycholesterol inhibits SRC-2 complex formation with RORa and RORg, thereby decreasing Bmall and Rev-erba expression, molecular components of the mammalian circadian clock (Wang et al. 2010). Thus, both SRC1 and SRC-2 regulate cholesterol synthesis through coordination of LXR/RXR- and LRH-1-driven gene transcription.

The SRCs regulate diverse metabolic processes in several key tissues, including the brain, liver, heart, and skeletal muscle, as well as in brown and white adipose tissue. For example, SRC-2 coactivates the bile acid receptor, farnesoid X receptor (FXR), in the liver to promote transcription of BSEP, the gene encoding the bile salt exports pump transporter protein, which is essential for bile acid transport and dietary fat absorption. As a result, SRC-2 deletion increases fecal triglycerides but decreases circulating plasma triglycerides and hepatic bile acid accumulation with reduced expression of bile acid synthesis genes Cyp7a1, Cyp8b1, Cyp7b1, Cyp27a1, and Ntcp (Chopra et al. 2011). As observed in adipose tissue, hepatic SRC-3 expression increases upon high fat diet (HFD) feeding (Ma et al. 2011). Loss of SRC-3 protects against HFD-induced hepatic steatosis by reducing lipid accumulation and the accompanying inflammatory response (Stashi et al. 2014). From oncological point of view, members of the steroid receptor coactivator (SRC) family are over-expressed in numerous types of cancers. In particular, SRC-3 (often designated under name AIB1) has been recognized as a critical coactivator, associated with tumor initiation, progres- sion, recurrence, metastasis, and chemoresistance, where it interacts with multiple nuclear receptors and other transcription factors to enhance their transcriptional activities and facilitate cross-talk between pathways that stimulate cancer progression. Because of its central role as an integrator of growth signaling pathways, the development of small molecule inhibitors (SMIs) against SRCs have a potential to simultaneously disrupt the multiple signal transduction networks and transcription factors involved in tumor progression.

Another level of complexity in this system can be achieved by posttranslational modifications (PTM) of proteins, specifically of SRCs. As an important consequence of their existence as multisubunit complexes, SRCs are able to transmit signals from the environment by supplying a variety of enzymatic activities at the promoters of the genes they regulate in an orderly way. For instance, the SRC-3 coactivator exists in a complex that includes kinases, ubiquitin ligases, ATPases, methyltransferases, acetylases and an alternative proteasome activator assembled together. Many other enzymatic capabilities reside in these coregulator complexes that have yet to be characterized (Jung et al. 2005), suggesting that still it is a lot work to do to be able to understand the full contributions of the coregulators provided for the regulation of transcription (Han et al. 2006). SRC-3 serves as a good example to demonstrate how a coregulator PTM code contributes to the biological complexity, signal integration, and the propagation of a biological program. Initially, SRC-3 is likely to be sumoylated (at amino acids 723 and 786) (Wu et al. 2007) and is hypophosphorylated at serine/threonine residues (Wu et al. 2004), existing as an inactive protein in its basal state. After phosphorylations at Ser 505/509 in a GSK3-dependent manner, SRC-3 becomes monoubiquitinated at amino acids 723 and 786 and is able to function as a potent and specific transcriptional activator (Wu et al. 2007). The ubiquitination sites are progressively polyubiquitinated during subsequent rounds of transcription, ultimately leading to its degradation by the $26 \mathrm{~S}$ proteasome. Independent of this, other phosphorylation sites in SRC-3 are targeted by other kinases and are necessary for SRC-3 to form divergent multiprotein complexes and coactivate its full range of transcription factors (Wu et al. 2004). However, PTMs have yet another mode how to play; SRC-3 can be methylated or acetylated leading so to coregulator complex disassembly. This, along with proteasome-mediated degradation, can contribute to the coregulator component dynamics, including turnover (Lee et al., 2005; Feng et al., 2006). 


\section{Combined and non-hormonal actions of SRCs}

As mentioned above, SRCs/NRCs have been originally identified and for a long time known as coregulators of NRs. Majority of the information come out from the in vitro studies, using stable cell lines, which naturally have their limitations. What makes SRCs even more interesting is the fact that they have also their own or NR-independent life. This property has not been comprehended adequately yet. In fact, it should not be surprising that due to their structural and domains' diversity, the SRCs display broader regulatory potential than that being associated with hormone signaling and NRs. This is prompting us to look at the SRCs family also as proteins with unexplored potential in developmental and broader comparative studies. Already early studies, using heterologous systems e.g. yeast twohybrid and mammalian coexpression systems, have shown that the magnitude of SRC-2/GRIP1 enhancement of liganded NR homodimer is dependent upon NR subtype and HRE configuration. For most HRE configurations, TR and RAR homodimers were essentially unresponsive or very weakly active in the absence of SRC-2/GRIP1, but SRC-2/GRIP1 dramatically restored the ligand-dependent function of these NRs. Although, SRC-2/GRIP1 exerted no significant effect on NR homodimers in the absence of their cognate ligands, it increased the transactivation of unliganded NR heterodimers (Walfish et al. 1997; Klinge et al. 2004), indicating that the transcription regulatory ability of SRC family members is their inherent property rather than being fully dependent on the liganded NR.

Another departure from the classical NRSRC scheme can be seen in a modulation of ERamediated gene regulation by a multimeric chromatin complex involving the two receptors and the coregulator RIP140 by aryl hydrocarbon receptor (AhR) (Matthews et al. 2005; Madak-Erdogan and Katzenellenbogen 2012). In addition, ligand activated dioxin receptor itself (heterodimer composed of two bHLH-PAS proteins, AhR and ARNT1) recruits SRC- 1 and or complex of ERa and SRC-1 to propagate dioxin receptor-mediated gene transcription (Mimura and Fujii-Kuriyama 2003; Beischlag et al. 2008; Endler et al. 2014). This type of interaction is often context- and/or enhancer-specific and can be dictated by the position of consensus hexanucleotide sequence known as the E-box within a target gene, such as CYP1A1. For instance, some of the dioxin (2,3,7,8-tetrachlorodibenzo- $p$-dioxin, known as TCDD)-bound AhR/ARNT signals can be mediated by GR/SRC-2 complex, rather than ER $\alpha$ and SRC-1 (Endler et al. 2014). The presence of SRC-1 or SRC-2 is essential for transcription initiation to unwind histone-bound DNA by exposing chromatin recognition sites to histone acetyltransferase (HAT) activity provided by SRC's HAT domain (Utley et al. 1998). Dutertre and Smith (2003) have provided evidence that interactions of SRC-1 or other p160/steroid receptor coactivators and CREB-binding protein (CBP) with ERa can be fully ligand-independent and regulated by phosphorylation sites (Ser104/106/118) in the A/B region of the ERa. Molnar et al. (2005) have identified some of the structural determinants of the agonist-independent association of human PPAR receptors with coactivators. Using PPAR $\gamma$ as target, they found that four different amino acid groups contribute to the ligand-independent stabilization of helix $\mathrm{H} 12$ of the PPAR ligand-binding domain. These amino acid groups include: (i) Lys329 and Glu499, mediating a charge clamp-type stabilization of helix $\mathrm{H} 12$ via a SRC bridge; (ii) Glu352, Arg425, and Tyr505, directly stabilizing the helix via salt bridges and hydrogen bonds; (iii) Lys347 and Asp503, interacting with each other as well as contacting the SRC; and (iv) His351, Tyr(355), His477, and Tyr501, forming a hydrogen bond network. These amino acids are highly conserved within the PPAR subfamily, suggesting that the same mechanism may apply for all three PPARs. Phylogenetic trees of helix H12 amino acid and nucleotide sequences of that time crystallized NRs and all human NRs, respectively, indicated a close relationship of PPARs with constitutive androstane receptor and other constitutive active members of the NR superfamily. Taking together, the ligand-independent tight control of the position of the PPAR helix H12 provides an effective alternative for establishing an interaction with SRC proteins. The importance of a specific DNA sequence within HRE as an allosteric effector of NR action has been further documented by Klinge et al. (2004) for ER and its EREs. Alterations in ER conformation induced by binding to different ERE sequences modulate ER interaction with coactivators and corepressors. $\mathrm{CHO}-\mathrm{K} 1$ cells transfected with ER $\alpha$ or ER $\beta$ show ERE sequence-dependent differences in the functional interaction of $\operatorname{ER} \alpha$ and $\operatorname{ER} \beta$ with SRC-1, SRC-2, SRC-3, then with ACTR, CBP, and steroid receptor RNA activator (SRA), as well as corepressors including NCoR and SMRT, and secondary coactivators such as coactivator associated arginine methyltransferase 1 (CARM1) and protein arginine methyltransferase 1 (PRMT1). Their data 
demonstrated that the ERE sequence impacts estradiol- and 4-hydroxytamoxifen-occupied as well as ligand-independent ER $\alpha$ and ER $\beta$ interaction with coregulators, as measured by transcriptional activity in mammalian cells.

Sort of interstep between the hormonal actions and divergence from classical coactivators' involvement, can be seen in ability of some NR receptors to recruit non-SRC bHLH-PAS proteins instead of particular SRC or ramification of the original hormonal signaling towards dioxin pathway. One of the first such unexpected deviations has been described by Rushing and Denison (2002) for RAR and TR silencing mediator's interaction with the AhR, which, however, failed to repress AhR-dependent gene expression. Very interesting was an observation of Widerak et al. (2006) who have found that AhR activates the RARa through SMRT antagonism. TCDD-bound AhR activated a subset of retinoid-dependent genes (tissue-transglutaminase, IGF binding protein-3, AhR) in MCF-7 breast cancer cells via stimulated transactivation by several class I heteromeric receptors (RAR and TR), while it antagonized homodimeric nuclear receptors (ER and PR). TCDD exerted a dose-dependent effect on a RARa-dependent reporter gene expressed in MCF-7 cells. AhR has been shown to be involved in a mutual antagonism with RARa corepressor SMRT. Ruegg et al. (2008) have described interaction of ER $\beta$ with ARNT in place of SRC-1 or SRC-3. This interaction was dominant for ER $\beta$ over ER $\alpha$ and mediated through A/B domain of ER $\beta$. In addition, this unusual biochemical behavior of $\operatorname{ER} \beta$ can result in alternative pathway mediating antiestrogenic effects of dioxin instead of estrogenic signaling.

On the other hand, perhaps complete absence of typical hormonal involvement in the SRC actions can be envisaged from the interaction of individual SRCs and related partners with non-NR proteins complexes. Nguyen et al. (1999) have found interaction of SRCs, ERAP140 and SMRT with AhR/ ARNT complex via co-immunoprecipitation and gel mobility shift assays by their binding to ${ }^{32} \mathrm{P}-$ dioxin response element (DRE), documenting that dioxin signaling can utilize NR coactivators and or corepressors for mediating own action. Currently, there is growing evidence, indicating that other bHLH-PAS pathways use SRCs or NR-machinery components for exerting their signaling ( $\mathrm{Xu}$ and Li 2003; York and O’Malley 2010). This is best exemplified by components of the circadian rhythms machinery such as Cycle, Clock, BMAL, and Period. The circadian clock orchestrates physiological and behavioral activities, including metabolism, neuronal activity, and cell proliferation in synchrony with the environmental cycle of day and night. BMAL1-Clock is a core transcription complex in the molecular circadian clock. Aryl hydrocarbon receptor nuclear translocator-like protein 1 is protein that in humans is encoded by the ARNTL gene also known as Bmall and plays a key role as one of the positive elements in the mammalian autoregulatory transcription translation negative feedback loop (TTFL), which is responsible for generating molecular circadian rhythms. BMAL1 has also been identified as a candidate gene for susceptibility to hypertension, diabetes, and obesity (Pappa et al. 2013; Richards et al. 2014) and mutations in Bmal1 have been linked to infertility, gluconeogenesis. BMAL1 binds with a second bHLH-PAS protein via the PAS domain, CLOCK to form a heterodimer in the nucleus (Huang et al. 2012). Via its bHLH domain, this heterodimer binds to E-box response elements (Wang et al. 2013) in the promoter regions of Per (Per1 and Per2) and Cry genes (Cry1 and Cry2) (Buhr and Takahashi 2013; Wang et al. 2013). This binding upregulates the transcription and translation of PER1, PER2, CRY1 and CRY2 proteins. After the PER and CRY proteins have accumulated to sufficient levels, they interact by their PAS motifs to form a large repressor complex that travels into the nucleus to inhibit the transcriptional activity of the CLOCK:BMAL1 heterodimer (Maywood et al. 2014). This inhibits the transcription of Per and Cry genes, and causes protein levels of PER and CRY drop. This complex transcriptional machinery is greatly mediated by interaction of BMAL/CLOCK heterodimer with SRC-1 or SRC-2 coactivators where no NRs are involved (Xu et al. 2009; Zhu et al. 2015; Liu et al. 2016; Morishita et al. 2016; Xiong et al. 2016).

\section{LXXLL as NR boxes and non-NR boxes: their diversity in proteins and practical implications}

As already indicated above, one of the key interaction, which is required for transduction of ligandbound NRs to SRCs, is mediated via amphipathic a-helical NR boxes, containing LXXLL motifs recognizing AF-2 groove within NR LBD (Shibata et al. 1997; Darimont 2003; Dutertre and Smith 2003; Loinder and Soderstrom 2004; Stashi et al. 2014). However, these amphipathic $\alpha$-helical LXXLL motifs participate in numerous different protein-protein interactions associated with different aspects of transcriptional regulation. These motifs are present in many other transcription factors and cofactors, me- 
diating interactions that can activate or repress transcription. Some coactivators are bifunctional, containing LXXLL motifs and domains that bind them. For example, a PAS-B domain in SRC-1 interacts with a LXXLL motif in the C-terminal transactivation domain of signal transducer and activator of transcription factor 6 (STAT6), which is a transcription factor involved in regulating the response to interleukin-4 (Litterst and Pfitzner 2002). Unlike the LXXLL motifs of SRC cofactors, the K1 residue of the STAT6 motif is polar. The crystallographic 3D structure of this interaction shows PAS-B to adopt a mixed a/b structure with the $a$-helical STAT6 peptide binding in a shallow hydrophobic groove (Razeto et al. 2004). The 3D structure also reveals several mechanistic differences in the LXXLL motif-binding mode compared with previous, NR-based complexes. For example, PAS-B does not employ a "charge-clamp" mechanism to tether the LXXLL a helix. Furthermore, the K1 residue does not contribute to the complex interface (Razeto et al. 2004). Interestingly, although many of the residues lining the LXXLL-binding site of PAS$\mathrm{B}$ are conserved throughout the NCoA family, only SRC-1 interacts with STAT6. Authors attribute this to a "surface complementarity" between SRC-1 PAS-B and STAT6.

$\mathrm{CBP} / \mathrm{p} 300$ also possesses the capacity to recognize LXXLL motifs. The KIX domain of CBP interacts with a LXXLL motif in the transactivation domain of c-Myb, which like STAT6, contains a polar K1 residue that is not involved in the interaction (Zor et al. 2004). The c-Myb motif binds to the same interface on KIX as the phosphorylated kinase-inducible domain (pKID) of CREB (Radhakrishnan et al. 1997; Zor et al. 2004).

E-proteins are another family of transcription factors that interact with $\mathrm{CBP} / \mathrm{p} 300$ via LXXLL motifs. E-proteins (e.g. E2A, HeLaE-box-binding (HEB) and E2-2) are involved in regulation of cell growth, differentiation, and apoptosis (Quong et al. 2002). In E-protein transactivation, $\mathrm{CBP} / \mathrm{p} 300$ is recruited by a LXXLL motif in the N-terminal activation domain 1 (AD1) (Zhang et al. 2004). This functionally crucial interaction is inhibited in the presence of AML1-ETO, a fusion protein commonly associated with acute myeloid leukemia (AML). Zhang and co-workers (2004) have demonstrated that AML1ETO specifically targets the E-protein LxxLL motif, thereby, directly preventing the binding of CBP/ p300. AML1-ETO is a fusion protein that results from $\mathrm{t}(8 ; 21)$ chromosomal translocations (Licht 2001). The LxxLL-binding activity of AML1-ETO was localized to the TATA-binding protein (TBP)-associated factor
(TAF) homology (TAFH; also called nervy-homology region 1, NHR1) domain from the fusion partner ETO (Zhang et al. 2004). The TAFH domain family which has examples in several TAFs from transcription factor IID (TFIID), other ETO-related proteins and the Drosophila protein nervy (Kokubo et al. 1993; Kitabayashi et al. 1998; Davis et al. 1999) had been functionally annotated, albeit loosely, as a proteinprotein interaction module. The results of Roeder and colleagues suggest the TAFH domain functions as one of a growing number of non-NR LXXLL-binding domains (Zhang et al. 2004).

The presence of TAFH domains in subunits of TFIID raises the possibility of direct regulation of the preinitiation RNA polymerase II complex by LXXLL-carrying proteins. Such a system has already been established for certain nuclear receptors that can interact with LxxLL motifs in Med1, a subunit of the mediator complex (Rachez et al. 2000). Currently, it remains to be established whether other members of the TAFH family are capable of interacting with LXXLL motifs. These observations raised the exciting possibility of using modified LxxLL-containing peptides as targeted inhibitors of the AML1-ETOE-protein complex or other LXXLL interactions involved in disease. Potentially, such molecules would not only provide substantial insight into the functional importance of regulatory interactions involving these motifs, but might also represent promising therapeutic strategies.

Indeed, in several recent years, there are numerous reports describing new LXXLL peptide mimetics often called also SRC small molecule inhibitors (SMIs) or SRC small molecule stimulators (SMS), which either prevent or potentiates activity of individual SRCs. The first were benzodiazepine derivatives selectively acting as LXXLL peptide mimetic inhibitors of the interaction of VDR with coactivators (Mita et al. 2010), followed by 2-aminoisobutyric acid containing leucine-based stapled short helical peptides (Demizu et al. 2013). More recent are gossypol cardiac glycoside buffalin, and protein synthesis inhibitor verrucarin A, both highly selective against SRC-3, although they show lowered activity also against SRC-1 (Wang et al. 2011, 2014; Yan et al. 2014). These inhibitors selectively promote the degradation of the SRC-3 protein, while affecting SRC-1 and SRC-2 to a lesser extent and having no impact on CARM-1 and p300 protein levels. Verrucarin A has been found to be cytotoxic toward multiple types of cancer cells at low nanomolar concentrations, but not toward normal liver cells. Up to now, most targeted chemotherapeutic drugs have been designed largely to block a single 
pathway at a time, but cancers frequently acquire resistance by switching to alternative growth factor pathways. These findings might represent promising development in a novel category of chemotherapeutic agents against SRC coactivators that sit at the nexus of the multiple cell growth signaling networks and transcriptional factors might be particularly effective drugs.

\section{Acknowledgements}

The research related to the articles topics in authors' laboratory was, in part, supported by grants of VEGA 2/0170/10, 2/0109/13, APVT-51-027402, NATO, CRG-972173 and LST.CLG-977559, MVTS32060600/EC-InSTRUCT-FP7-211252, and EEA-Norwegian FM SK-0086 (grant to R.F).

\section{References}

An BS, Selva DM, Hammond GL, Rivero-Muller A, Rahman N, Leung PC. Steroid receptor coactivator-3 is required for progesterone receptor trans-activation of target genes in response to gonadotropin-releasing hormone treatment of pituitary cells. J Biol Chem 281, 20817-20824, 2006.

Awais M, Sato M, Umezawa Y. Imaging of selective nuclear receptor modulator-induced conformational changes in the nuclear receptor to allow interaction with coactivator and corepressor proteins in living cells. Chembiochem 8, 737-743, 2007.

Beischlag TV, Luis Morales J, Hollingshead BD, Perdew GH. The aryl hydrocarbon receptor complex and the control of gene expression. Crit Rev Eukaryot Gene Expr 18, 207-250, 2008.

Bisson WH, Cheltsov AV, Bruey-Sedano N, Lin B, Chen J, Goldberger N, May LT, Christopoulos A, Dalton JT, Sexton PM, Zhang XK, Abagyan R. Discovery of antiandrogen activity of nonsteroidal scaffolds of marketed drugs. Proc Natl Acad Sci USA 104, 11927-11932, 2007.

Black JC, Choi JE, Lombardo SR, Carey M. A mechanism for coordinating chromatin modification and preinitiation complex assembly. Mol Cell 23, 809-818, 2006.

Buhr ED, Takahashi JS. Molecular components of the mammalian circadian clock. In: Handbook of Experimental Pharmacology (Ed. A Kramer, M Merrow), 217, pp. 3-27, 2013.

Buzon V, Carbo LR, Estruch SB, Fletterick RJ, Estebanez-Perpina E. A conserved surface on the ligand binding domain of nuclear receptors for allosteric control. Mol Cell Endocrinol 348, 394-402, 2012.

Carlsson P, Koehler KF, Nilsson L. Glucocorticoid receptor point mutation V571M facilitates coactivator and ligand binding by structural rearrangement and stabilization. Mol Endocrinol 19, 1960-1977, 2005.

Chang AK, Wu H. The role of AIB1 in breast cancer. Oncol Lett 4, 588-594, 2012.

Chaudhary J, Skinner MK. Basic helix-loop-helix proteins can act at the E-box within the serum response element of the c-fos promoter to influence hormone-induced promoter activation in Sertoli cells. Mol Endocrinol 13, 774-786, 1999.

Chen JD, Evans RM. A transcriptional co-repressor that interacts with nuclear hormone receptors. Nature 377, 454457, 1995.

Chopra AR, Kommagani R, Saha P, Louet JF, Salazar C, Song J, Jeong J, Finegold M, Viollet B, DeMayo F, Chan L, Moore DD, O’Malley BW. Cellular energy depletion resets whole-body energy by promoting coactivatormediated dietary fuel absorption. Cell Metab 13, 35-43, 2011.

Costantino G, Entrena-Guadix A, Macchiarulo A, Gioiello A, Pellicciari R. Molecular dynamics simulation of the ligand binding domain of farnesoid X receptor. Insights into helix-12 stability and coactivator peptide stabilization in response to agonist binding. J Med Chem 48, 3251-3259, 2005.

Darimont BD. Finding specificity within a conserved interaction site. Chem Biol 10, 675-676, 2003.

Dasgupta S, Lonard DM, O’Malley BW. Nuclear receptor coactivators: master regulators of human health and disease. Annu Rev Med 65, 279-292, 2014.

Davis JN, Williams BJ, Herron JT, Galiano FJ, Meyers S. ETO-2, a new member of the ETO-family of nuclear proteins. Oncogene 18, 1375-1383, 1999.

Demizu Y, Nagoya S, Shirakawa M, Kawamura M, Yamagata N, Sato Y, Doi M, Kurihara M. Development of stapled short helical peptides capable of inhibiting vitamin D receptor (VDR)-coactivator interactions. Bioorg Med Chem Lett 23, 4292-4296, 2013.

Ding L, Yang L, Wang Z, Huang W. Bile acid nuclear receptor FXR and digestive system diseases. Acta Pharm Sin B5 135-144, 2015. 
D’Rozario M, Zhang T, Waddell EA, Zhang Y, Sahin C, Sharoni M, Hu T, Nayal M, Kutty K, Liebl F, Hu W, Marenda DR. Type I bHLH Proteins Daughterless and Tcf4 Restrict Neurite Branching and Synapse Formation by Repressing Neurexin in Postmitotic Neurons. Cell Rep 15, 386-397, 2016.

Dutertre M, Smith CL. Ligand-independent interactions of p160/steroid receptor coactivators and CREB-binding protein (CBP) with estrogen receptor-alpha: regulation by phosphorylation sites in the A/B region depends on other receptor domains. Mol Endocrinol 17, 1296-1314, 2003.

Elhaji YA, Stoica I, Dennis S, Purisima EO, Lumbroso R, Beitel LK, Trifiro MA. Impaired helix 12 dynamics due to proline 892 substitutions in the androgen receptor are associated with complete androgen insensitivity. Hum Mol Genet 15, 921-31, 2006.

Endler A, Chen L, Shibasaki F. Coactivator recruitment of AhR/ARNT1. Int J Mol Sci 15, 11100-11110, 2014.

Evans RM. The steroid and thyroid hormone receptor superfamily. Science 240, 889-895, 1988.

Farah MH, Olson JM, Sucic HB, Hume RI, Tapscott SJ, Turner DL. Generation of neurons by transient expression of neural bHLH proteins in mammalian cells. Development 127, 693-702, 2000.

Feng Q, Yi P, Wong J, O’Malley BW. Signaling within a coactivator complex: methylation of SRC-3/AIB1 is a molecular switch for complex disassembly. Mol Cell Biol 26, 7846-7857, 2006.

Fidelak J, Ferrer S, Oberlin M, Moras D, Dejaegere A, Stote RH. Dynamic correlation networks in human peroxisome proliferator-activated receptor- $\gamma$ nuclear receptor protein. Eur Biophys J 39, 1503-1512, 2010.

Gallastegui N, Mackinnon JA, Fletterick RJ, Estebanez-Perpina E. Advances in our structural understanding of orphan nuclear receptors. Trends Biochem Sci 40, 25-35, 2015.

Gehin M, Mark M, Dennefeld C, Dierich A, Gronemeyer H, Chambon P. The function of TIF2/GRIP1 in mouse reproduction is distinct from those of SRC-1 and p/CIP. Mol Cell Biol 22, 5923-5937, 2002.

Gupte R, Muse GW, Chinenov Y, Adelman K, Rogatsky I. Glucocorticoid receptor represses proinflammatory genes at distinct steps of the transcription cycle. Proc Natl Acad Sci USA 110, 14616-14621, 2013.

Han SJ, Jung SY, Malovannaya A, Kim T, Lanz RB, Qin J, O’Malley BW. A scoring system for the follow up study of nuclear receptor coactivator complexes. Nucl Recept Signal 4, e014, 2006.

Han SJ, Hawkins SM, Begum K, Jung SY, Kovanci E, Qin J, Lydon JP, DeMayo FJ, O‘Malley BW. A new isoform of steroid receptor coactivator-1 is crucial for pathogenic progression of endometriosis. Nature Med 18, 1102-1111, 2012.

Harms MJ, Eick GN, Goswami D, Colucci JK, Griffin PR, Ortlund EA, Thornton JW. Biophysical mechanisms for large-effect mutations in the evolution of steroid hormone receptors. Proc Natl Acad Sci USA 110, 1147511480, 2013.

He B, Kemppainen JA, Wilson EM. FXXLF and WXXLF sequences mediate the $\mathrm{NH}_{2}$-terminal interaction with the ligand binding domain of the androgen receptor. J Biol Chem 275, 22986-22994, 2000.

Hefti MH, Françoijs KJ, de Vries SC, Dixon R, Vervoort J. The PAS fold. A redefinition of the PAS domain based upon structural prediction. Eur J Biochem 27, 1198-208, 2004.

Heldin CH, Lu B, Evans R, Gutkind JS. Signals and Receptors. Cold Spring Harb Perspect Biol 8, 2016.

HjaltT.Basichelix-loop-helixproteinsexpressedduringearlyembryonicorganogenesis. IntRevCytol236,251-280,2004.

Hong H, Kohli K, Garabedian MJ, Stallcup MR. GRIP1, a transcriptional coactivator for the AF-2 transactivation domain of steroid, thyroid, retinoid, and vitamin D receptors. Mol Cell Biol May 17, 2735-2744, 1997.

Hsieh HT, Wang CH, Wu ML, Yang FM, Tai YC, Hu MC. PIASy inhibits LRH-1-dependent CYP11A1 expression by competing for SRC-1 binding. Biochem J 419, 201-209, 2009.

Hsu CL, Chen YL, Yeh S, Ting HJ, Hu YC, Lin H, Wang X, Chang C. The use of phage display technique for the isolation of androgen receptor interacting peptides with $(\mathrm{F} / \mathrm{W}) \mathrm{XXL}(\mathrm{F} / \mathrm{W})$ and FXXLY new signature motifs. J Biol Chem 278, 23691-23698, 2003.

Huang N, Chelliah Y, Shan Y, Taylor CA, Yoo SH, Partch C, Green CB, Zhang H, Takahashi JS. Crystal structure of the heterodimeric CLOCK:BMAL1 transcriptional activator complex. Science 337, 189-194, 2012.

Hughes TS, Chalmers MJ, Novick S, Kuruvilla DS, Chang MR, Kamenecka TM, Rance M, Johnson BA, Burris TP, Griffin PR, Kojetin DJ. Ligand and receptor dynamics contribute to the mechanism of graded PPAR $\gamma$ agonism. Structure 20, 139-150, 2012.

Jasuja R, Ulloor J, Yengo CM, Choong K, Istomin AY, Livesay DR, Jacobs DJ, Swerdloff RS, Miksovska J, Larsen RW, Bhasin S. Kinetic and thermodynamic characterization of dihydrotestosterone-induced conformational perturbations in androgen receptor ligand-binding domain. Mol Endocrinol 23, 1231-1241, 2009.

Jones S. An overview of the basic helix-loop-helix proteins. Genome Biol 5, 226, 2004.

Jung SY, Malovannaya A, Wei J, O’Malley BW, Qin J. Proteomic analysis of steady-state nuclear hormone receptor coactivator complexes. Mol Endocrinol 19, 2451-2465, 2005. 
Kastner P, Mark M, Chambon P. Nonsteroid nuclear receptors: what are genetic studies telling us about their role in real life? Cell 83, 859-869, 1995.

Kim MS, Sweeney TR, Shigenaga JK, Chui LG, Moser A, Grunfeld C, Feingold KR. Tumor necrosis factor and interleukin 1 decrease RXRalpha, PPARalpha, PPARgamma, LXRalpha, and the coactivators SRC-1, PGC1alpha, and PGC-1beta in liver cells. Metabolism 56, 267-279, 2007.

King-Jones K, Thummel CS. Nuclear receptors - a perspective from Drosophila. Nature Rev Genet 6, 311-323, 2005.

Kitabayashi I, Ida K, Morohoshi F, Yokoyama A, Mitsuhashi N, Shimizu K, Nomura N, Hayashi Y, Ohki M. The AML1-MTG8 leukemic fusion protein forms a complex with a novel member of the MTG8(ETO/CDR) family, MTGR1. Mol Cell Biol 18, 846-858, 1998.

Klinge CM, Jernigan SC, Mattingly KA, Risinger KE, Zhang J. Estrogen response element-dependent regulation of transcriptional activation of estrogen receptors alpha and beta by coactivators and corepressors. J Mol Endocrinol 33, 387-410, 2004.

Kokubo T, Gong DW, Roeder RG, Horikoshi M, Nakatani Y. The Drosophila 110-kDa transcription factor TFIID subunit directly interacts with the N-terminal region of the $230-\mathrm{kDa}$ subunit. Proc Natl Acad Sci USA 90, 5896-5900, 1993.

Laffitte BA, Kast HR, Nguyen CM, Zavacki AM, Moore DD, Edwards PA. Identification of the DNA binding specificity and potential target genes for the farnesoid X-activated receptor. J Biol Chem 275, 10638-10647, 2000.

Lee YH, Coonrod SA, Kraus WL, Jelinek MA, Stallcup MR. Regulation of coactivator complex assembly and function by protein arginine methylation and demethylimination. Proc Natl Acad Sci USA 102, 3611-3616, 2005.

Leo C, Chen JD. The SRC family of nuclear receptor coactivators. Gene 245, 1-11, 2000.

$\mathrm{Li} \mathrm{H}$, Chen JD. The receptor-associated coactivator 3 activates transcription through CREB-binding protein recruitment and autoregulation. J Biol Chem 273, 5948-5954, 1998.

Licht JD. AML1 and the AML1-ETO fusion protein in the pathogenesis of $t(8 ; 21)$ AML. Oncogene 20, 5660-5679, 2001.

Litterst CM, Pfitzner E. An LxxLL motif in the transactivation domain of STAT6 mediates recruitment of NCoA-1/ SRC-1. J Biol Chem 277, 36052-36060, 2002.

Littlewood TD, Evan GI. Transcription factors 2: helix-loop-helix. Protein Profile 1, 635-709, 1994.

Liu J, Zhou B, Yan M, Huang R, Wang Y, He Z, Yang Y, Dai C, Wang Y, Zhang F, Zhai Q. CLOCK and BMAL1 regulate muscle insulin sensitivity via SIRT1 in male mice. Endocrinology, en20152027, 2016. [Epub ahead of print]

Loinder K, Soderstrom M. Functional analyses of an LXXLL motif in nuclear receptor corepressor (N-CoR). J Steroid Biochem Mol Biol 91, 191-196, 2004.

Ma X, Xu L, Wang S, Cui B, Li X, Xu J, Ning G. Deletion of steroid receptor coactivator-3 gene ameliorates hepatic steatosis. J Hepatol 55, 445-452, 2011.

Mackinnon JA, Gallastegui N, Osguthorpe DJ, Hagler AT, Estebanez-Perpina E. Allosteric mechanisms of nuclear receptors: insights from computational simulations. Mol Cell Endocrinol 393, 75-82, 2014.

Madak-Erdogan Z, Katzenellenbogen BS. Aryl hydrocarbon receptor modulation of estrogen receptor a-mediated gene regulation by a multimeric chromatin complex involving the two receptors and the coregulator RIP140. Toxicol Sci 125, 401-411, 2012.

Mangelsdorf DJ, Thummel C, Beato M, Herrlich P, Schutz G, Umesono K, Blumberg B, Kastner P, Mark M, Chambon P, Evans RM. The nuclear receptor superfamily: the second decade. Cell 83, 835-839, 1995.

Mascrez B, Ghyselinck NB, Watanabe M, Annicotte JS, Chambon P, Auwerx J, Mark M. Ligand-dependent contribution of RXRbeta to cholesterol homeostasis in Sertoli cells. EMBO Rep 5, 285-290, 2004.

Matthews J, Wihlen B, Thomsen J, Gustafsson JA. Aryl hydrocarbon receptor-mediated transcription: ligand-dependent recruitment of estrogen receptor alpha to 2,3,7,8-tetrachlorodibenzo-p-dioxin-responsive promoters. Mol Cell Biol 25, 5317-5328, 2005.

Maywood ES, Chesham JE, Smyllie NJ, Hastings MH. The Tau mutation of casein kinase $1 \varepsilon$ sets the period of the mammalian pacemaker via regulation of Period1 or Period 2 clock proteins. J Biol Rhyth 29, 110-118, 2014.

Metivier R, Penot G, Flouriot G, Pakdel F. Synergism between ERalpha transactivation function 1 (AF-1) and AF-2 mediated by steroid receptor coactivator protein-1: requirement for the AF-1 alpha-helical core and for a direct interaction between the N- and C-terminal domains. Mol Endocrinol 15, 1953-1970, 2001.

Mimura J, Fujii-Kuriyama Y. Functional role of AhR in the expression of toxic effects by TCDD. Biochim Biophys Acta 1619, 263-268, 2003.

Mita Y, Dodo K, Noguchi-Yachide T, Miyachi H, Makishima M, Hashimoto Y, Ishikawa M. LXXLL peptide mimetics as inhibitors of the interaction of vitamin D receptor with coactivators. Bioorg Med Chem Lett 20, 1712-1717, 2010. 
Molnar F, Matilainen M, Carlberg C. Structural determinants of the agonist-independent association of human peroxisome proliferator-activated receptors with coactivators. J Biol Chem 280, 26543-2656, 2005.

Morishita Y, Miura D, Kida S. PI3K regulates BMAL1/CLOCK-mediated circadian transcription from the Dbp promoter. Biosci Biotechnol Biochem 80, 1131-1140, 2016.

Mouchon A, Delmotte MH, Formstecher P, Lefebvre P. Allosteric regulation of the discriminative responsiveness of retinoic acid receptor to natural and synthetic ligands by retinoid X receptor and DNA. Mol Cell Biol 19, 3073-3085, 1999.

Murphy KA, Quadro L, White LA. The intersection between the aryl hydrocarbon receptor (AhR)- and retinoic acidsignaling pathways. Vitam Horm 75, 33-67, 2007.

Musille PM, Pathak MC, Lauer JL, Hudson WH, Griffin PR, Ortlund EA. Antidiabetic phospholipid-nuclear receptor complex reveals the mechanism for phospholipid-driven gene regulation. Nat Struct Mol Biol 19, 532-537, 2012.

Nagy L, Kao HY, Love JD, Li C, Banayo E, Gooch JT, Krishna V, Chatterjee K, Evans RM, Schwabe JW. Mechanism of corepressor binding and release from nuclear hormone receptors. Genes Dev 13, 3209-3216, 1999.

Nguyen TA, Hoivik D, Lee JE, Safe S. Interactions of nuclear receptor coactivator/corepressor proteins with the aryl hydrocarbon receptor complex. Arch Biochem Biophys 367, 250-257, 1999.

Norman AW. Identification of a unique nuclear receptor for 9-cis retinoic acid. Nutr Rev 50, 230-231, 1992.

O’Malley BW. Coregulators: from whence came these 'master genes'. Mol Endocrinol 21, 1009-1013, 2007.

Onate SA, Tsai SY, Tsai MJ, O’Malley BW. Sequence and characterization of a coactivator for the steroid hormone receptor superfamily. Science 270, 1354-1357, 1995.

Osborne CK, Bardou V, Hopp TA, Chamness GC, Hilsenbeck SG, Fuqua SA, Wong J, Allred DC, Clark GM, Schiff R. Role of the estrogen receptor coactivator AIB1 (SRC-3) and HER-2/neu in tamoxifen resistance in breast cancer. J Natl Cancer Inst 95, 353-361, 2003.

Osguthorpe DJ, Hagler AT. Mechanism of androgen receptor antagonism by bicalutamide in the treatment of prostate cancer. Biochemistry 50, 4105-4113, 2011.

Osguthorpe DJ, Sherman W, Hagler AT. Generation of receptor structural ensembles for virtual screening using binding site shape analysis and clustering. Chem Biol Drug Des 80, 182-193, 2012.

Pappa KI, Gazouli M, Anastasiou E, Iliodromiti Z, Antsaklis A, Anagnou NP. The major circadian pacemaker ARNT-like protein-1 (BMAL1) is associated with susceptibility to gestational diabetes mellitus. Diabetes Res Clin Pract 99, 151-157, 2013.

Paramanik V, Thakur MK. AIB1 shows variation in interaction with ER $\beta$ TAD and expression as a function of age in mouse brain. Biogerontology 12, 321-328, 2011.

Parker MG, White R. Nuclear receptors spring into action. Nat Struct Biol 3, 113-115, 1996.

Percharde M, Lavial F, Ng JH, Kumar V, Tomaz RA, Martin N, Yeo JC, Gil J, Prabhakar S, Ng HH, Parker MG, Azuara V. Ncoa3 functions as an essential Esrrb coactivator to sustain embryonic stem cell self-renewal and reprogramming. Genes Dev 26, 2286-2298, 2012.

Pogenberg V, Guichou JF, Vivat-Hannah V, Kammerer S, Perez E, Germain P, de Lera AR, Gronemeyer H, Royer CA, Bourguet W. Characterization of the interaction between retinoic acid receptor/retinoid X receptor (RAR/ RXR) heterodimers and transcriptional coactivators through structural and fluorescence anisotropy studies. J Biol Chem 280, 1625-1633, 2005.

Ponting CP, Aravind L. PAS: a multi-functional domain family comes to light. Curr Biol 7, R674-R677, 1997.

Presman DM, Alvarez LD, Levi V, Eduardo S, Digman MA, Marti MA, Veleiro AS, Burton G, Pecci A. Insights on glucocorticoid receptor activity modulation through the binding of rigid steroids. PLoS One 5, e13279, 2010.

Pugh BF. HATs off to PIC assembly. Molec Cell 23, 776-777, 2006.

Qin L, Liu Z, Chen H, Xu J. The steroid receptor coactivator-1 regulates twist expression and promotes breast cancer metastasis. Cancer Res 69, 3819-3827, 2009.

Quong MW, Romanow WJ, Murre C. E protein function in lymphocyte development. Annu Rev Immunol 20, 301322, 2002.

Rachez C, Gamble M, Chang CP, Atkins GB, Lazar MA, Freedman LP. The DRIP complex and SRC-1/p160 coactivators share similar nuclear receptor binding determinants but constitute functionally distinct complexes. Mol Cell Biol 20, 2718-2726, 2000.

Radhakrishnan I, Perez-Alvarado GC, Parker D, Dyson HJ, Montminy MR, Wright PE. Solution structure of the KIX domain of CBP bound to the transactivation domain of CREB: a model for activator:coactivator interactions. Cell 91, 741-752, 1997. 
Razeto A, Ramakrishnan V, Litterst CM, Giller K, Griesinger C, Carlomagno T, Lakomek N, Heimburg T, Lodrini M, Pfitzner E, Becker S. Structure of the NCoA-1/SRC-1 PAS-B domain bound to the LXXLL motif of the STAT6 transactivation domain. J Mol Biol 336, 319-329, 2004.

Richards J, Diaz AN, Gumz ML. Clock genes in hypertension: novel insights from rodent models. Blood Pres Monitor 19, 249-254, 2014.

Rushing SR, Denison MS. The silencing mediator of retinoic acid and thyroid hormone receptors can interact with the aryl hydrocarbon (Ah) receptor but fails to repress Ah receptor-dependent gene expression. Arch Biochem Biophys 403, 189-201, 2002.

Ruegg J, Swedenborg E, Wahlstrom D, Escande A, Balaguer P, Pettersson K, Pongratz I. The transcription factor aryl hydrocarbon receptor nuclear translocator functions as an estrogen receptor beta-selective coactivator, and its recruitment to alternative pathways mediates antiestrogenic effects of dioxin. Mol Endocrinol 22, 304-316, 2008.

Sachs LM, Shi YB. Targeted chromatin binding and histone acetylation in vivo by thyroid hormone receptor during amphibian development. Proc Natl Acad Sci USA 97, 13138-13143, 2000.

Sachs LM, Amano T, Rouse N, Shi YB. Involvement of histone deacetylase at two distinct steps in gene regulation during intestinal development in Xenopus laevis. Dev Dyn 222, 280-291, 2001.

Sheppard HM, Harries JC, Hussain S, Bevan C, Heery DM. Analysis of the steroid receptor coactivator 1 (SRC1)CREB binding protein interaction interface and its importance for the function of SRC1. Mol Cell Biol 21, 39-50, 2001.

Shibata H, Spencer TE, Onate SA, Jenster G, Tsai SY, Tsai MJ, O’Malley BW. Role of co-activators and co-repressors in the mechanism of steroid/thyroid receptor action. Recent Prog Horm Res 52, 141-64, 1997.

Shiota M, Yokomizo A, Tada Y, Inokuchi J, Tatsugami K, Kuroiwa K, Uchiumi T, Fujimoto N, Seki N, Naito S. Peroxisome proliferator-activated receptor $\gamma$ coactivator-1 $\alpha$ interacts with the androgen receptor (AR) and promotes prostate cancer cell growth by activating the AR. Mol Endocrinol 24, 114-127, 2009.

Son YL, Lee YC. Molecular determinants of the interactions between SRC-1 and LXR/RXR heterodimers. FEBS Lett 584, 3862-3866, 2010.

Souza PC, Barra GB, Velasco LF, Ribeiro IC, Simeoni LA, Togashi M, Webb P, Neves FA, Skaf MS, Martinez L, Polikarpov I. Helix 12 dynamics and thyroid hormone receptor activity: experimental and molecular dynamics studies of Ile280 mutants. J Mol Biol 412, 882-893, 2011.

Spencer TE, Jenster G, Burcin MM, Allis CD, Zhou J, Mizzen CA, McKenna NJ, Onate SA, Tsai SY, Tsai MJ, O’Malley BW. Steroid receptor coactivator-1 is a histone acetyltransferase. Nature 389, 194-198, 1997.

Stashi E, Wang L, Mani SK, York B, O'Malley BW. Research resource: loss of the steroid receptor coactivators confers neurobehavioral consequences. Mol Endocrinol 27, 1776-1787, 2013.

Stashi E, York B, O’Malley BW. Steroid receptor coactivators: servants and masters for control of systems metabolism. Trends Endocrinol Metab 25, 337-347, 2014.

Sterner DE, Berger SL. Acetylation of histones and transcription-related factors. Microbiol Mol Biol Rev 64, 435-459, 2000.

Taylor BS, Schultz N, Hieronymus H, Gopalan A, Xiao Y, Carver BS, Arora VK, Kaushik P, Cerami E, Reva B, Antipin Y, Mitsiades N, Landers T, Dolgalev I, Major JE, Wilson M, Socci ND, Lash AE, Heguy A, Eastham JA, Scher HI, Reuter VE, Scardino PT, Sander C, Sawyers CL, Gerald WL. Integrative genomic profiling of human prostate cancer. Cancer Cell 18, 11-22, 2010.

Torchia J, Rose DW, Inostroza J, Kamei Y, Westin S, Glass CK, Rosenfeld MG. The transcriptional co-activator p/CIP binds CBP and mediates nuclear-receptor function. Nature 387, 677-684, 1997.

Tyteca S, Legube G, Trouche D. To die or not to die: a HAT trick. Mol Cell 24, 807-808, 2006.

Uhlenhaut NH, Barish GD, Yu RT, Downes M, Karunasiri M, Liddle C, Schwalie P, Hubner N, Evans RM. Insights into negative regulation by the glucocorticoid receptor from genome-wide profiling of inflammatory cistromes. Mol Cell 49, 158-171, 2013.

Utley RT, Ikeda K, Grant PA, Cote J, Steger DJ, Eberharter A, John S, Workman JL. Transcriptional activators direct histone acetyltransferase complexes to nucleosomes. Nature 394, 498-502, 1998.

van de Wijngaart DJ, van Royen ME, Hersmus R, Pike AC, Houtsmuller AB, Jenster G, Trapman J, Dubbink HJ. Novel FXXFF and FXXMF motifs in androgen receptor cofactors mediate high affinity and specific interactions with the ligand-binding domain. J Biol Chem 281, 19407-19416, 2006.

van de Wijngaart DJ, Dubbink HJ, van Royen ME, Trapman J, Jenster G. Androgen receptor coregulators: recruitment via the coactivator binding groove. Mol Cell Endocrinol 352, 57-69, 2012.

VoN, Goodman RH.CREB-binding protein and p300in transcriptional regulation.JBiol Chem 276, 13505-13508,2001. 
Walfish PG, Yoganathan T, Yang YF, Hong H, Butt TR, Stallcup MR. Yeast hormone response element assays detect and characterize GRIP1 coactivator-dependent activation of transcription by thyroid and retinoid nuclear receptors. Proc Natl Acad Sci USA 94, 3697-3702, 1997.

Walsh CA, Qin L, Tien JC, Young LS, Xu J. The function of steroid receptor coactivator-1 in normal tissues and cancer. Int J Biol Sci 8, 470-485, 2012.

Wang Y. Downregulation of liver X receptor in mouse kidney and HK-2 proximal tubular cells by LPS and cytokines. J Lipid Res 46, 2377-2387, 2005.

Wang Z, Burke PA. Modulation of hepatocyte nuclear factor-4alpha function by the peroxisome-proliferator-activated receptor-gamma co-activator-1alpha in the acute-phase response. Biochem J 415, 289-296, 2008.

Wang Y, Kumar N, Crumbley C, Griffin PR, Burris TP. A second class of nuclear receptors for oxysterols: Regulation of RORalpha and RORgamma activity by 24S-hydroxycholesterol (cerebrosterol). Biochim Biophys Acta 1801, 917-923, 2010.

Wang Y, Lonard DM, Yu Y, Chow DC, Palzkill TG, O’Malley BW. Small molecule inhibition of the steroid receptor coactivators, SRC-3 and SRC-1. Molec Endocrinol 25, 2041-2053, 2011.

Wang Z, Wu Y, Li L, Su XD. Intermolecular recognition revealed by the complex structure of human CLOCKBMAL1 basic helix-loop-helix domains with E-box DNA". Cell Res 23, 213-224, 2013.

Wang Y, Lonard DM, Yu Y, Chow DC, Palzkill TG, Wang J, Qi R, Matzuk AJ, Song X, Madoux F, Hodder P, Chase P, Griffin PR, Zhou S, Liao L, Xu J, O’Malley BW. Bufalin is a potent small-molecule inhibitor of the steroid receptor coactivators SRC-3 and SRC-1. Cancer Res 74, 1506-1517, 2014.

Weber D, Wiese C, Gessler M. Hey bHLH transcription factors. Curr Top Dev Biol 110, 285-315, 2014.

Widerak M, Ghoneim C, Dumontier MF, Quesne M, Corvol MT, Savouret JF. The aryl hydrocarbon receptor activates the retinoic acid receptor alpha through SMRT antagonism. Biochimie 88, 387-397, 2006.

Wolf G. Cellular retinoic acid-binding protein II: a coactivator of the transactivation by the retinoic acid receptor complex RAR.RXR. Nutr Rev 58, 151-153, 2000.

Wu JH, Gottlieb B, Batist G, Sulea T, Purisima EO, Beitel LK, Trifiro M. Bridging structural biology and genetics by computational methods: an investigation into how the R774C mutation in the AR gene can result in complete androgen insensitivity syndrome. Hum Mutat 22, 465-475, 2003.

Wu RC, Qin J, Yi P, Wong J, Tsai SY, Tsai MJ, O’Malley BW. Selective phosphorylations of the SRC-3/AIB1 coactivator integrate genomic reponses to multiple cellular signaling pathways. Mol Cell 24, 937-949, 2004.

Wu RC, Feng Q, Lonard DM, O’Malley BW. SRC-3 coactivator functional lifetime is regulated by a phospho-dependent ubiquitin time clock. Cell 129, 1125-1140, 2007.

Wurtz JM, Bourguet W, Renaud JP, Vivat V, Chambon P, Moras D, Gronemeyer H. A canonical structure for the ligand-binding domain of nuclear receptors. Nat Struct Biol 3, 206, 1996.

Xiong W, Li J, Zhang E, Huang H. BMAL1 regulates transcription initiation and activates circadian clock gene expression in mammals. Biochem Biophys Res Commun 473, 1019-1025, 2016.

Xu J, Liao L, Ning G, Yoshida-Komiya H, Deng C, O’Malley BW. The steroid receptor coactivator SRC-3 (p/CIP/ RAC3/ AIB1/ACTR/TRAM-1) is required for normal growth, puberty, female reproductive function, and mammary gland development. Proc Natl Acad Sci USA 97, 6379-6384, 2000.

$\mathrm{Xu}$ J, Li Q. Review of the in vivo functions of the p160 steroid receptor coactivator family. Mol Endocrinol 17, 16811692, 2003.

$\mathrm{Xu}$ J, Wu RC, O’Malley BW. Normal and cancer-related functions of the p160 steroid receptor co-activator (SRC) family. Nature Rev Cancer 9, 615-630, 2009.

Xu X, Yang W, Wang X, Li Y, Wang Y, Ai C. Dynamic communication between androgen and coactivator: mutually induced conformational perturbations in androgen receptor ligand-binding domain. Proteins 79, 1154-1171, 2011.

Yamamoto KR. Steroid receptor regulated transcription of specific genes and gene networks. Annu Rev Genet 19, 209-215, 1985.

Yan F, Yu Y, Chow DC, Palzkill T, Madoux F, Hodder P, Chase P, Griffin PR, O’Malley BW, Lonard DM. Identification of verrucarin a as a potent and selective steroid receptor coactivator-3 small molecule inhibitor. PLoS One 9, e95243, 2014.

York B, O’Malley BW. Steroid receptor coactivator (SRC) family: masters of systems biology. J Biol Chem 285, 3874338750, 2010.

Zakharov MN, Pillai BK, Bhasin S, Ulloor J, Istomin AY, Guo C, Godzik A, Kumar R, Jasuja R. Dynamics of coregulator-induced conformational perturbations in androgen receptor ligand binding domain. Mol Cell Endocrinol 341, 1-8, 2011. 
Zelenko Z, Aghajanova L, Irwin JC, Giudice LC. Nuclear receptor, coregulator signaling, and chromatin remodeling pathways suggest involvement of the epigenome in the steroid hormone response of endometrium and abnormalities in endometriosis. Reprod Sci 19, 152-162, 2012.

Zhang J, Kalkum M, Yamamura S, Chait BT, Roeder RG. E protein silencing by the leukemogenic AML1-ETO fusion protein. Science 305, 1286-1289, 2004.

Zhou G, Cummings R, Li Y, Mitra S, Wilkinson HA, Elbrecht A, Hermes JD, Schaeffer JM, Smith RG, Moller DE. Nuclear receptors have distinct affinities for coactivators: characterization by fluorescence resonance energy transfer. Mol Endocrinol 12, 1594-604, 1998.

Zhu B, Gates LA, Stashi E, Dasgupta S, Gonzales N, Dean A, Dacso CC, York B, O’Malley BW. Coactivator-Dependent Oscillation of Chromatin Accessibility Dictates Circadian Gene Amplitude via REV-ERB Loading. Mol Cell 60, 769-783, 2015.

Zor T, De Guzman RN, Dyson HJ, Wright PE. Solution structure of the KIX domain of CBP bound to the transactivation domain of c-Myb. J Mol Biol 337, 521-534, 2004. 